\title{
МОНІТОРИНГ ЕФЕКТИВНОСТІ ДІЯЛЬНОСТІ ПІДПРИЕМСТВ ТРАНСПОРТНОї ГАЛУЗІ РЕГІОНУ
}

\author{
Машканцева Світлана Олександрівна \\ кандидат економічних наук, доцент \\ Національний університет «Одеська морська академія» \\ ORCID 0000-0002-3936-9812 \\ volodymyr@wiktoriya.com
}

У статті визначено рівень ефективності діяльності підприємств транспортної галузі регіону за допомогою аналізу показників приведеної собівартості перевезення, рентабельності діяльності, чистого прибутку (збитку) від діяльності підприємств. Запропоновано заходи щодо забезпечення подальшого розвитку підприємств транспортної галузі на регіональному рівні. Визначено, що сучасний стан трансформаційних перетворень у регіональному середовищі характеризується зростаючим інтересом до питань підвищення ефективності діяльності підприємств транспортної галузі. Об'єктивна оцінка ефрективності діяльності підприємств транспортної галузі має велике значення, оскільки характеризує успішність менеджменту підприємства, формує його імідж, обгрунтовує доиільність інвестицій.

Ключові слова: моніторинг ефективності, транспортна галузь, регіон, рентабельність, собівартість перевезення, підприємства транспортної галузі.

DOl: https://doi.org/10.32845/bsnau.2019.4.13

Постановка проблеми у загальному вигляді та їі зв'язок із важливими науковими чи практичними завданнями. Конкурентоспроможність та ефективність транспортної системи визначається не стільки існуванням окремих видів транспорту, скільки їх модальною інтероперабельністью та інтегрованістю на регіональному, національному та міжнародному рівнях. Транспорт $є$ невід'ємною, інтегруючою усі процеси (від постачання ресурсів до реалізації продукції) складовою виробничо-комерційної діяльності підприємств. Ефективність транспортної галузі формується на двох рівнях за участю трьох суб'єктів: транспорту, споживачів транспортних послуг і державних органів, що забезпечують згладжування протиріч між суб'єктом транспортної системи і двома іншими суб'єктами.

Науковці пропонують різні методики вивчення стану та ефективності функціонування транспортної галузі регіону в цілому. Так, наприклад, В.В. Волошин, М.В. Григорович, Е.Ф. Коценко доводять, що дослідження доцільно проводити в два етапи. На першому етапі проаналізувати географічне розташування, природні ресурси, рівень економічного розвитку та галузеву структуру транспортної галузі регіону. На другому етапі здійснити оцінку особливостей розвитку кожного із видів транспорту регіону у територіальному і функціональному аспектах [1, с. 63].

Н.I. Коноваловою запропоновано методику вивчення діяльності суб'єктів господарювання транспортної галузі у такій послідовності:

I. Значення транспорту в забезпеченні вантажних та пасажирських перевезень, у розвитку внутрішніх і зовнішніх економічних зв'язків.

II. Історія формування транспортної мережі, етапи розвитку та роль кожного виду транспорту в господарстві регіону на кожному з них.

III. Транспортна система регіону, види транспорту, структура вантажо- та пасажирообігу. звитку.

4. Географія шляхової мережі, умови та фактори ії ро-

5. Географрія вантажо- й пасажироперевезень.

6. Якісна характеристика транспорту: склад робочої сили, придатність і ступінь використання транспортних засобів і комунікацій.

7. Екологічні аспекти транспортної проблеми [2, с. 55]. Описані методики оцінки ефективності діяльності підприємств транспортної галузі регіону представляють собою сукупність показників, які відображають взаємозв'язок всіх видів транспорту між собою, координацію і технологічну єдність їх роботи.

Аналіз останніх досліджень і публікацій, в яких започатковано розв'язання даної проблеми і на які спирається автор, виділення невирішених раніше частин загальної проблеми, котрим присвячується означена стаття. Питання ефективності функціонування і розвитку підприємств транспортної галузі досліджуються такими вченими, як Б. Анікін, Д. Бауерсокс, А. Гаджинський, О. Глогусь, Є. Голіков, А. Кальченко, Є. Крикавський, Л. Міротін, Ю. Неруш, В. Ніколайчук,Ю.Пономарьова, О. Семененко, І. Смирнов, И. Ташбаєв, Н. Чухрай тощо. Водночас, незважаючи на значну кількість досліджень ефективних конфігурацій та методичних підходів до аналізу економічної ефекктивності діяльності підприємств транспортної галузі, існує потреба у всебічному обгрунтуванні спроможності забезпечити розвиток галузі на регіональному рівні з урахуванням властивостей діяльності усіх видів транспорту.

Формулювання цілей статті (постановка завдання). Метою статті $є$ аналіз показників ефективності функціонування підприємств транспортної галузі регіону для розробки та обгрунтування пропозицій щодо перспектив їх інноваційного розвитку в сучасних умовах.

Виклад основного матеріалу дослідження 3 повним обґрунтуванням отриманих наукових результатів. Ефективність транспортування вантажів оцінюється рівнем витрат, які залежать від регулярності поставок, ступеню схоронності вантажів, швидкості їх доставки. На собівартість перевезень впливає обсяг перевезень, дальність перевезення вантажів, величина якісних показників використання рухомого складу, застосування нових прогресивних видів техніки і технології, нормування трудових і матеріальних ресурсів, продуктивність праці (табл. 1).

В 2018 році порівняно 32010 роком показник приведеної собівартості перевезення вантажів зріс в 3,5 рази, що пояснюється збільшенням операційних витрат в 3,1 рази та скороченням вантажообігу на 10,7 \%. Основними напрямами

Вісник Сумського національного аграрного університету

Серія «Економіка і менеджмент», випуск 4 (82), 2019 
зменшення собівартості перевезення вантажів є: використання прогресивної техніки та технології; покращення рівня якості діяльності підприємств транспортної галузі; зростання продуктивності праці; підвищення ефективності використання основних засобів; скорочення норм витрат ресурсів на одиницю перевезень у натуральному виразі.

Таблиця 1

\section{Розрахунок приведеної собівартості перевезення вантажів}

\begin{tabular}{|c|c|c|c|}
\hline Роки & $\begin{array}{c}\text { Операційні витрати, } \\
\text { млн. грн }\end{array}$ & Вантажообіг, млн. ткм & $\begin{array}{c}\text { Приведена собівартість } \\
\text { перевезень, грн/ткм }\end{array}$ \\
\hline 2010 & 170064,9 & 404572,9 & 0,42 \\
\hline 2014 & 224131,9 & 335151,7 & 0,67 \\
\hline 2015 & 330153,5 & 315341,8 & 1,05 \\
\hline 2016 & 371017,3 & 323473,9 & 1,15 \\
\hline 2017 & 462049,9 & 343057,1 & 1,35 \\
\hline 2018 & 531018,5 & 361353,5 & 350,0 \\
\hline 2018 р. в \% до 2010 р. & 312,2 & 89,3 & \\
\hline
\end{tabular}

"розраховано за даними Державної служби статистики України [3]

Чистий прибуток (збиток) від діяльності підприємств характеризує оцінку економічної ефрективності функціонування підприємств транспортної галузі (табл. 2).

В цілому по Україні в 2010 році отримано чистий прибуток від діяльності підприємств транспортної галузі на рівні 3792,9 млн. грн, в 2018 році отримано чистий збиток від діяльності транспортної галузі в сумі 22365,3 млн. грн. Тобто за період 2010-2018pp. діяльність транспортної галузі розвивається нестабільно. На кожен прибутковий рік припадає два збиткових. Проте, в розрізі регіонів цей показник коливається. Протягом 2010-2018 років збільшення суми чистого прибутку від діяльності транспортної галузі спостерігається в
Київській та Одеській областях відповідно на 1875,4млн. грн і 2831,8 млн. грн. За досліджуваний період сума збитку від діяльності транспортної галузі значно зросла в областях: Донецькій, Дніпропетровській. Ступінь прибутковості діяльності підприємств $є$ основним стимулюючим чинником для подальшого розвитку та розширення сфрери транспортних послуг.

Дослідження показали, що об'єктивна оцінка ефективності діяльності підприємств транспортної галузі має велике значення, оскільки характеризує успішність менеджменту підприємства, формує його імідж, обгрунтовує доцільність інвестицій.

Таблиия 2

Динаміка чистого прибутку (збитку) від діяльності підприємств транспортної галузі регіонів України, млн.грн *

\begin{tabular}{|c|c|c|c|c|c|c|c|}
\hline \multirow{2}{*}{$\begin{array}{c}\text { Адміністративно-територіальні } \\
\text { одиниці }\end{array}$} & \multicolumn{6}{|c|}{ Роки } & \multirow{2}{*}{$\begin{array}{c}\text { 2018p. до 2010p., } \\
(+,-)\end{array}$} \\
\hline & 2010 & 2014 & 2015 & 2016 & 2017 & 2018 & \\
\hline Автономна Республіка Крим & 62,3 & - & - & - & - & - & - \\
\hline Вінницька & $-34,1$ & $-432,5$ & $-536,8$ & $-218,6$ & $-283,1$ & 132,4 & $+166,5$ \\
\hline Волинська & $-23,9$ & $-46,0$ & $-47,2$ & 104,9 & 143,9 & 155,0 & $+178,9$ \\
\hline Дніпропетровська & $-417,7$ & $-3017,6$ & $-1997,5$ & $-309,2$ & 418,5 & $-1306,8$ & $-889,1$ \\
\hline Донецька & 634,5 & 467,9 & $-1103,3$ & 540,6 & 27,2 & $-615,2$ & $-1249,7$ \\
\hline Житомирська & $-9,4$ & $-31,2$ & $-26,4$ & $-58,7$ & $-106,8$ & $-142,0$ & $-132,6$ \\
\hline Закарпатська & $-3,4$ & $-111,8$ & $-417,2$ & 839,9 & 88,7 & 68,5 & $+71,9$ \\
\hline Запорізька & $-12,3$ & $-13,8$ & 216,7 & 277,4 & 61,8 & $-91,7$ & $-79,4$ \\
\hline Івано-Франківська & $-105,9$ & $-640,7$ & $-91,7$ & $-28,3$ & $-251,3$ & $-99,2$ & $+6,7$ \\
\hline Київська & 173,0 & $-2325,0$ & $-3947,3$ & 1332,7 & 1969,2 & 2048,4 & $+1875,4$ \\
\hline Кіровоградська & $-42,9$ & $-124,5$ & $-57,3$ & $-11,9$ & $-3673,5$ & 64,9 & $+107,8$ \\
\hline Луганська & $-8,6$ & $-3622,7$ & $-33,7$ & 7,3 & 22,0 & $-24,3$ & $-15,7$ \\
\hline Львівська & 36,8 & $-360,3$ & 15,9 & $-824,5$ & 33,2 & 394,3 & $+357,5$ \\
\hline Миколаївська & 421,3 & $-686,6$ & $-89,2$ & 895,9 & 1174,0 & 1282,1 & $+860,8$ \\
\hline Одеська & 390,1 & $-6039,8$ & $-3790,6$ & 321,8 & 3058,8 & 3221,9 & $+2831,8$ \\
\hline Полтавська & $-20,5$ & $-904,6$ & $-565,5$ & 340,1 & 681,8 & 665,3 & 686,8 \\
\hline Рівненська & 17,2 & $-149,7$ & $-227,8$ & 102,4 & $-22,5$ & 3,6 & $-13,6$ \\
\hline Сумська & $-35,8$ & $-297,1$ & $-320,9$ & $-110,8$ & $-18,9$ & $-90,8$ & $-55,0$ \\
\hline Тернопільська & $-5,6$ & $-728,1$ & $-768,5$ & $-264,6$ & $-301,0$ & $-114,8$ & $-109,2$ \\
\hline Харківська & $-365,9$ & $-764,0$ & $-639,3$ & $-369,7$ & $-10,0$ & 9,1 & $+375,0$ \\
\hline Херсонська & $-11,5$ & $-39,7$ & 59,3 & 165,4 & 49,9 & $-31,6$ & $-20,1$ \\
\hline Хмельницька & $-7,9$ & $-262,4$ & $-176,0$ & $-37,5$ & $-6,8$ & 47,9 & $+55,8$ \\
\hline Черкаська & $-33,2$ & $-212,9$ & $-135,7$ & 1,2 & $-105,7$ & 104,2 & $+137,4$ \\
\hline Чернівецька & $-13,0$ & $-62,6$ & $-32,5$ & $-27,7$ & 9,1 & $-10,8$ & $+2,2$ \\
\hline Чернігівська & $-27,7$ & $-239,3$ & $-283,3$ & $-67,0$ & 8,8 & 47,2 & $+74,9$ \\
\hline м. Київ & 3113,9 & $-5662,3$ & $-3105,1$ & 4406,2 & $-19417,0$ & $-28082,9$ & $-31196,8$ \\
\hline м. Севастополь & 123,1 & - & - & - & - & - & - \\
\hline Україна & 3792,9 & $-26307,3$ & $-18100,9$ & 7007,3 & $-16449,7$ & $-22365,3$ & $-26158,2$ \\
\hline
\end{tabular}

*розраховано за даними Державної служби статистики України [3]

У цілісній системі аналізу ефективності діяльності під- | приємств транспортної галузі показнику рентабельності на- 
лежить провідне місце через комплексність та інформативність цієї економічної категорії (табл. 3). Рівень рентабельності операційної діяльності підприємств транспортної галузі в 2018 році порівняно з 2010 роком скоротився на 0,3 в.п., при цьому рівень рентабельності всієї діяльності підприємств транспортної галузі зріс на 1,5 в.п. На рівень рентабельності діяльності підприємств транспортної галузі впливають зовні- шні фактори (географфічне розташування; державне регулювання; рівень конкуренції і попиту на транспортні послуги тощо) та внутрішні фрактори (технологічність процесу надання транспортних послуг та рівень оновлення обладнання; оптимальність чисельності виробничого персоналу та фонду робочого часу; ефективність організації праці; достатність наявного обсягу основних засобів тощо).

Таблиия 3

Рентабельність операційної та всієї діяльності підприємств транспортної галузі, \%*

\begin{tabular}{|c|c|c|}
\hline Роки & $\begin{array}{c}\text { Рівень рентабельності (збитковості) операційної діяльності } \\
\text { підприємств }\end{array}$ & $\begin{array}{c}\text { Рівень рентабельності (збитковості) всієї діяльності } \\
\text { підприємств }\end{array}$ \\
\hline 2010 & 4,7 & 0,7 \\
\hline 2014 & $-2,1$ & $-8,5$ \\
\hline 2015 & 0,6 & $-4,7$ \\
\hline 2016 & 4,3 & 3,8 \\
\hline 2017 & 0,6 & $-0,9$ \\
\hline 2018 & 4,4 & 2,2 \\
\hline 2018 р. до 2010 р., в.п. & $-0,3$ в.п. & 1,5 в.п. \\
\hline
\end{tabular}

“розраховано за даними Державної служби статистики України [3]

Транспортна галузь забезпечує поєднання виробництва продукції та її споживання через процес перевезення вантажів, зв'язуючи регіони України між собою, а також з іншими державами [4]. Слід відмітити, що розвитку набуває автомобільний транспорт, тому що саме він $є$ сполучним елементом між всіма іншими видами транспорту і споживачами транспортних послуг. Крім того, будівництво транспортних артерій інших видів $€$ неможливим без участі автомобільного транспорту. Наявність розгалуженої мережі автомобільних шляхів, їх технічний стан є індикаторами розвитку суспільства, оскільки суттєво впливають на темпи розвитку суспільства; рівень витрат з перевезення вантажів; швидкість, якість, вартість перевезення; мобільність, зайнятість і рівень доходів населення; екологічний стан навколишнього середовища тощо [5, c. 46]. Основний каркас залізничної колії складає густу мережу сильно завантажених широтних і меридіональних ліній, що мають численні примикання під'їзних шляхів промислових підприємств. На під'їзних коліях здійснюється більш 80 \% від загального навантаження залізниці.

Наявність інфраструктурних мереж є важливою передумовою для розвитку транспортної галузі регіонів України. Економічне зростання регіону значною мірою обумовлено функціональністю транспортної інфраструктури, яка здатна забезпечити дієвість переміщення та якісне обслуговування. Відсутність розвиненої транспортної інфраструктури $є$ найбільш проблемним питанням укріплення економічного потенціалу регіонів і перешкоджає широкому залученню сучасного новітнього виробництва, його технічного та технологічного оновлення, широкого залучення до процесу виробництва ре- сурсної бази окремих регіонів, посилення зв'язків між виробничими та обслуговуючими галузями, укріплення господарських зв'язків між віддаленими територіями. Ефективне транспортне забезпечення регіонів України передбачає виконання двох умов:

- створення необхідної кількості об'єктів транспорту у регіоні з урахуванням його площі, населення, виробничих та побутових потреб;

- забезпечення можливостей для використання існуючого потенціалу регіону та створення передумов для його нарощування.

Висновки 3 даного дослідження і перспективи подальших розвідок у даному напрямку. За останні десять років збільшилась кількість проблемних питань ефективного функціонування транспортної галузі в системі мультимодальних перевезень як України в цілому, так і її регіонів. За таких умов особлива увага зосереджується на ефективній взаємодії різних видів транспорту. На практиці досить часто перевезення вантажів одним видом транспорту стає не можливим і вимагає залучення інших видів, що спонукає до планування транспортних процесів на різних видах транспорту, переходу на інформаційно-логістичні методи обслуговування. Нерозвиненими є механізми конкуренції та самоорганізації підприємств транспортної галузі в системі мультимодальних перевезень, а державне регулювання є недостатньо дієвим. Глобалізаційні процеси та євроінтеграційні умови висувають нові вимоги до діяльності підприємств транспортної галузі в системі мультимодальних перевезень, проте здійснювана державна політика не відповідає цим викликам.

\section{Список використаної літератури:}

1. Волошин В.В., Григорович М.В., Коценко Е.Ф. Транспортная система региона. АН УССР. Ин-т геофизики им. С.И. Субботина. Отд-ние географии. К.: Наук. думка, 1989. 206 с.

2. Коновалова Н.І. Методика соціальних та економіко-географічних досліджень. Чернівці: Рута, 1998. 88 с.

3. Транспорт і зв'язок України у 2018. Статистичний збірник. К. : Державна служба статистики України. 2019. 186 с.

4. Лагодиенко В.В. Понятие сущности и функций управления в логистических системах / В.В. Лагодиенко, А.В. Корниецкий // Балтийский гуманитарный журнал.- 2014.- №4(9).-С. 145-147.

5. Заблодська І. В., Бузько І. Р., Зеленко О. О., Хорошилова І. О. Інфраструктурне забезпечення розвитку транспортної системи регіону: колективна монографія. Сєвєродонецьк: Вид-во СНУ ім. В. Даля, 2016. 193 с. 
Mashkantseva S.O., PhD, Associate professor, Odesa National Maritime Academy (Odesa, Ukraine)

Monitoring the efficiency of enterprises in the transport sector of the region.

The article determines the level of efficiency of enterprises in the transport sector of the region by analyzing the indicators of the reduced cost of transportation, profitability, net profit (loss) from the activities of enterprises.

It is established that the availability of infrastructure networks is an important prerequisite for the development of the transport sector of the regions of Ukraine. The economic growth of the region is largely due to the functionality of transport infrastructure, which is able to ensure the efficiency of movement and quality service. Lack of developed transport infrastructure is the most problematic issue of strengthening the economic potential of regions and prevents the widespread involvement of modern production, its technical and technological renewal, broad involvement in the production process of the resource base of individual regions, strengthening ties between industries and services, strengthening economic ties. languages between remote areas.

Studies have shown that in practice quite often the transportation of goods by one mode of transport becomes impossible and requires the involvement of other types, which encourages the planning of transport processes on different modes of transport, the transition to information and logistics methods of service. The mechanisms of competition and self-organization of transport enterprises in the system of multimodal transportation are underdeveloped, and state regulation is insufficiently effective. Globalization processes and European integration conditions put forward new requirements for the activity of transport enterprises in the system of multimodal transportation, but the implemented state policy does not meet these challenges.

Measures to ensure the further development of transport enterprises at the regional level are proposed. An objective assessment of the efficiency of the transport industry is of great importance, as it characterizes the success of the management of the enterprise, forms its image, justifies the feasibility of investment.

Effective transport support of the regions of Ukraine involves the fulfillment of two conditions:

- creation of the required number of transport facilities in the region, taking into account its area, population, industrial and domestic needs;

- providing opportunities for using the existing potential of the region and creating preconditions for its expansion.

Key words: efficiency monitoring, transport industry, region, profitability, transportation cost, transport industry enterprises.

Дата надходження до редакції: 21.10.2019 р. 